\title{
Implementation of Oral Questioning in Assessing Student Learning In Mathematics Teaching In Primary Schools
}

\author{
Muhammad Sofwan Mahmud ${ }^{1}$, Tajularipin Sulaiman', Ahmad FauziMohd Ayub ${ }^{3}$, Aida Suraya \\ Md. Yunus ${ }^{4}$ \\ ${ }^{1}$ Faculty of Education, Universiti Kebangsaan Malaysia, Malaysia \\ ${ }^{234}$ Faculty of Educational Studies, Universiti Putra Malaysia, Malaysia \\ sofwanmahmud@ukm.edu.my ${ }^{1}$
}

Article History: Received: 11 January 2021; Accepted: 27 February 2021; Published online: 5 April 2021

\begin{abstract}
POral questioning has various roles in teaching mathematics and is often used as one of the strategies for assessing student learning formatively. However, not much is known about how primary school mathematics teachers use oral questioning to assess student learning because previous studies have focused more on oral questioning in general in terms of its implementation in teaching. Therefore, this study was conducted to explore how primary school mathematics teachers use oral questioning to assess student learning in mathematics teaching. This study is qualitative in the form of a case study involving six school mathematics teachers selected using the purposive sampling method. Data for this study were collected using observation methods, interviews and field notes. Next, the data obtained were analysed using constant comparative analysis using Atlas ti. 8 software to obtain themes and sub-themes. The study found that oral questioning helps teachers gather information about student learning to improve, make decisions on teaching and ensures that students master the topics taught. Thus, it is clear that oral questioning has a broad role in teaching, especially in assessing student learning while improving teaching quality. This study has a significant impact on teachers' instruction. The use of oral questioning needs to be intensified and expanded to enable mathematics teaching activities to be implemented more meaningfully through a formative assessment conducted through oral questioning activities.
\end{abstract}

Keywords: Oral Questioning, Formative Assessment, Teaching Mathematics, Primary School.

\subsection{Introduction}

The use of oral questioning as a technique in performing an assessment, especially in the classroom, is seen as an important matter due to its use, which strongly correlates with the teaching process (Wong, 2015). This indirectly illustrates that oral questioning is widely used in the teaching process, and it certainly has its role in ensuring that a learning objective can be achieved(Mahmud et al., 2020c).Besides, Iksan and Daniel (2015)stated that oral questioning plays a role as a measuring stick in the teaching process and also student learning. Through oral questioning in formative assessment, teachers will be able to find out a variety of information from students to be used as data to improve the quality of teaching and student learning (Cauley \& McMillan, 2010). Besides, oral questioning that uses various levels allows teachers to assess students' thinking and helps students be more involved in the teaching and learning process while increasing student motivation for learning(Mahmud, 2019). The students themselves can also find out the extent of knowledge and understanding they have achieved through oral questioning activities. This coincides with the need found in the formative assessment itself where, among the purposes of formative implementation, is that students can enhance their learning as well as build their internal motivation(Nancy \& Frey, 2015).

In addition, the use of oral questioning in teaching and learning mathematics will be the basis and foundation for the implementation of practical formative assessment(Good, 2011). Teaching is said to be meaningless without oral questioning activities. This is because oral questioning provides a platform for teachers to collect information holistically, covering knowledge, attitudes, skills and values. Oral questioning, which is also conducted embedded with formative assessment, was found to meet the school assessment characteristics set by the Ministry of Education Malaysia, which is holistic, inclusive, authentic, local, flexible and continuous. The standard allows information to be obtained and will be used by teachers to plan follow-up actions to improve and enhance student learning (Curriculum Development Division, 2014).

In addition, oral questioning as a formative assessment technique allows teachers to interact directly with students. It will enable teachers to understand the actual situation of students' answers based on the environment, socioeconomic background of students, and even seen from the aspect of gender (Shahrill, 2013). This is supported by many studies, including Kim et al., (2011)and studies by Watt et al., (2012)who have reported that communication between teachers and students is influenced by gender, social class and teachers 'perceptions of students' abilities. The information obtained through teacher questioning activities and students' direct answers provides a better platform for teachers to gather data, make assessmentsand make decisions to improve student learning. This is highly emphasised by the ministry, where all aspects are taken into account in helping teachers 
decide on the results of formative assessments implemented. The feedback given by teachers has an impact on improving student learning and is holistic (Desli \& Galanopoulou, 2017)

Oral questioning as a technique in implementing formative assessment or assessment for learning should provide space for students to be actively involved in the teaching and learning process carried out (Boulter, 2010) other than one way of imparting knowledge and lesson content to its students (Zakaria \& Addenan, 2015). However, a few teachers are still weak in applying questioning techniques in their teaching activities, where they focus more on one-way teaching methods by using the method of 'chalk and talk(Mahmud et al., 2020a). This has indirectly caused the teaching and learning process to occur only in one way, and students do not have the space to be actively involved in teaching activities carried out. This also results in teachers not gathering sufficient information as required for formative assessment (Belcher, 2016). The data collected should be used by teachers to improve the quality of students' teaching and learning.

Kassim and Zakaria (2013) also stated that the use of questioning by teachers, especially in the teaching and learning of mathematics, is still low, and that it is still procedural and algorithmic. This indirectly causes teachers to fail to collect information and evidence of student learning and causes a lack of student involvement in following the teaching and learning process (Franke et al., 2009). This is very important to meet the formative assessment's needs where teachers collect information about student learning. That information is used to improve students' weaknesses in learning. Thus, it is clear here that practical oral communication skills in the teaching and learning process play a huge role in gathering information in formative assessment. Through it, teachers can provide feedback on student learning, improving student learning on information obtained(Dibbs, 2014). Therefore, it is essential to make a comprehensive study to evaluate the implementation of oral questioning practice in primary schools as an important formative assessment technique.

In the teaching process, curriculum and thinking skills are embedded. Harlen (2004) states that during the implementation of formative assessment of elements, thinking skills, knowledge, understanding of concepts, and attitudes can be trained. Therefore, to ensure that the assessment conducted can apply all these elements, teachers must act to ensure that students can achieve learning objectives and decide on teaching measures that should be taken according to student achievement. Effective and continuous formative assessment practices can train students' thinking skills to a higher level and even make them more active in every activity carried out in the learning process. However, this situation only occurs when the teacher uses the information obtained from the formative assessments made. Then, the teacher decides the next teaching step that is appropriate to the need to improve student learning (Buhagiar, 2014).

\subsection{Problem statement}

As we know, oral questioning is one of the strategies often used by teachers to implement formative assessment in mathematics teaching. This is because it is closely related to teachers' teaching practices. Through formative assessment using oral questioning strategies, teachers can gather information to improve their teaching and student learning (Mutalib \& Ahmad, 2012). However, Mahmud and Yunus (2018)found that many teachers only understand oral questioning as a standard questioning process used in the teaching process instead of focusing on formative assessment. Teachers think that oral questioning is only used to help students understand and remember the lesson's content and is not used in assessing student learning. The implementation of effective oral questioning should serve as a tool that can help teachers gather a variety of information about the level of student learning, enabling teachers to improve such learning. The lack of understanding of teachers on this matter causes formative assessment activities to be less implemented comprehensively in teaching mathematics. This is also supported bySach (2012), who found that teachers' knowledge of oral questioning to implement formative assessment is still at a low level.

Nevertheless, based on the problem statements that have been discussed so far, too little is known of the perceptions of primary school mathematics teachers in implementing formative assessment using oral questioning in the teaching process. This is because most of the previous studies on oral questioning only focused on secondary school mathematics teachers. Very few studies were conducted leading to oral questioning in mathematics subjects in primary schools. Although researchon oral questioning has been for several years, it is still a relatively new study in mathematics education, especially in primary schools. Thus, this study is expected to show the actual scenario of how the practice of oral questioning is implemented by primary school mathematics teachers so that problems that arise can be identified and thensolved through several proposed solutions. This study was conducted to explore how primary school mathematics teachers implement formative assessment using oral questioning in implementing mathematics teaching.

\subsection{Methodology}

This study is a qualitative study that uses various case study methods (Merriam \& Tisdell, 2016). The selection of this method fits the research questions that need to be answered because the case study allows a comprehensive picture, complete and in-depth understanding related to the implementation of oral questioning among mathematics teachers in primary schools. Six primary schools in a district in Negeri Sembilan were selected as study sites to explore and understand the practice of teachers' oral questioning in teaching 
mathematics. The selection of this district as the study location is based on Marshall and Rossman (2014)who state that the characteristics of the place to conduct the study should be easily accessible, no barriers to conduct the study, have a high opportunity to collect in-depth data, have the freedom to research and be easy for study participants to participate, as well as in lessons.

Six primary school mathematics teachers from six different schools, three of whom were new teachers and three experienced teachers, were selected as study participants using the purposive sampling method. The selection of study participants for this study is based on the researcher's criteria and characteristics, namely mathematics option teachers, teaching mathematics subjects in primary schools, and the teachers' willingness to participate in this study.

Researchers use methods of observation, interviews, document analysis and field notes to collect data. The use of various data collection techniques can help researchers triangulate data at the data analysis level while strengthening the findings obtained (Miles, Huberman, \& Saldana, 2014). In this study, the researcher's method to analyse the data is to use the constant comparative analysis method to see the patterns and themes contained in the data obtained where this data are the primary data (Kolb, 2012). The constant comparison method is the core of the qualitative study to see the similarities and differences of each theme. This process is a data encoding process in which the data are broken down to be screened and then interpreted meaningfully to construct a theme. This process is essential to help researchers rearrange 'chunks' of data to be categorised and to facilitate researchers to group sections related to specific research questions and themes. Researchers use three levels of qualitative data coding, namely open coding, axial coding, and choose where coding. The similarities and differences of each theme obtained help the researcher make comparisons between new teachers and experienced teachers. Then, similar articles are grouped in one category, and this process of comparison will continue until the data reaches the saturation stage (Marshall \& Rossman, 2014). The data collected in this study were analysed using Atlas. Ti 8 software to obtain themes and sub-themes. In this study, the researchers have used several methods to improve the study's validity and reliability by using the triangulation method, consent of study participants, peer review, audit trail, researcher bias and a long period in the field.

\subsection{Findings}

Findings of the study are that primary school mathematics teachers use oral questions as formative assessments to gather information about student learning, make decisions on the instructional process and ensure students master the learning topics taught.

\subsection{Gathering information about student learning}

The study's findings found that there are various purposes of oral questions asked to students as a formative assessment of them during the process of teaching mathematics being carried out. Assessment questions asked to students also aim to gather information about how student learning can be improved. For example, the question serves to ensure that students can follow the explanation presented and monitor their understanding. Thus, the information obtained through assessment questions can be used by teachers to improve the quality of their teaching. Teacher Azah explains this in the following passage.

"As teachers, we need always to know the level of learning when students are being implemented. Through oral questioning, teachers can monitor students' understanding and gather information about student learning to improve teaching activities implemented."

[Azah,SRI2/21344-21587]

Usually, the teacher asks the assessment questions after an explanation is given or after introducing a new concept to the students. The following are examples of assessment questions asked by study participants after giving explanations to students:

"Do you get it?"

[Ana, P1/7338-7363]

"Do you understand?"

[Roza, P1/3583-3589]

"Can you do it?"

[Nadia,P2/5726-5774]

"Okay, do you understand that?"

[Raha, P3/13137-13184]

The above questions also ask students to serve as a measuring stick for students' understanding in following the lessons implemented. Teacher Ada explained this in a follow-up interview session that was conducted. Such questions can provide teachers information about the level of students and help teachers gather a wealth of information to plan activities that are more appropriate to the needs of students [Ada, SRI 2/19764-19793]. 


\subsection{Make decisions on the instructional process}

Through formative assessment activities conducted through oral questioning, the information gathered about student learning allows teachers to make the same decision to give interventions to students or proceed with new subtopics. This is explained by Ms. Nadia in the following interview excerpt:

"When we ask students, we can know whether the students understand or not what we teach them. So it can help teachers to decide whether to repeat the lesson, provide an intervention or continue with a new sub -topic. "'

[Nadia,SRI2/19319-21152]

Teacher Roza and Teacher Ana also expressed the same opinion in the follow-up interview sessions [Roza, SRI 1/5127-5169] and [Ana, SRI 1/22524-22830]. The following shows how teachers make decisions on the mathematics instruction process based on information gathered through assessment questions:

Teacher: What is the shape of RSTU?

Students: It is square.

Teacher: What is the length of $R U$ and $S T$ ?

Student: $12 \mathrm{~cm}$..

Teacher: So now, can you solve the question?

Students: Yes, we can.

Teacher: Okay, calculate the perimeter of RSTU. What is the answer?

Student : $163 \mathrm{~cm}$..

Teacher: Do you understand? All right, take out your math exercise book. Please

answer questions $a, b, c, d$, e. Please do it now and draw the diagram.

[Nadia, P1/10122-10446]

Teacher Nadia asked the students a question about the rectangle's side measurements to find the perimeter of the rectangle. Students were found to give the correct answer for each question asked, causing Teacher Nadia to decide to continue teaching to the next step. Also, Teacher Nadia explained that such questions are essential to help teachers make decisions on the teaching of mathematics conducted as well as help teachers plan interventions on areas that students do not directly control [Nadia, SRI3/973-1343]

\subsection{Ensures that students master the topics taught}

Apart from asking questions like "Do you understand?", "Can I?", "Can I come along?" etc., as assessment questions, there are also situations where teachers ask questions by repeating the same question several times to assess students' understanding of the teaching process implemented. In this context, the same question is asked several times to students to master the topic taught. It also becomes 'evidence' or confirmation proof to the teacher to proceed to a new teaching topic [Ada, NL/24092018]. The passage below shows an example of repetition of questions done by Teacher Ada to find out the position of students' understanding and knowledge to move to other sub-topics:

Teacher: This is a connected line. So do we have to take this? We want the

circumference. This one we have to take or not?

Students: Take.

Teacher: Okay. This one?! (Refer to the same questions)

Students: Take.

Teacher: Okay, good. So please remember that we take the circumference. Inside

line not involve. Understand class?

[Ada, P1/9143-9244]

Based on the repetition of the questions posed by Teacher Ada to the students about the required side in the perimeter calculation and the students' correct response, it showed that she was able to decide to proceed to the next teaching step. However, Teacher Ada explained that, if the student's answer is negative or incorrect, she is willing to repeat the concept that has been explained or give more time to the student to think to provide a more accurate answer [Ada, SRI1/30523-30703].

Thus it can be understood that teachers use assessment questions to monitor student learning. The information obtained by the teacher through the responses given by the students after asking the assessment questions helps the teacher either to continue teaching to a new topic or repeat the teaching through intervention activities appropriate to the needs of the students at that time. This can indirectly help teachers to improve the quality of their education and help improve student learning.

\subsection{Discussion}

\section{Assessing Students' Learning Through Oral Questioning}

Teachers were found to ask questions as a formative assessment in the mathematics teaching process implemented. Assessment questions such as "can I?" and "don't you understand so far?" were presented to students to help teachers gather information about student learning. Then that information is used to help students improve their learning and improve teacher teaching quality, as stated by Weiland et al. (2014) in their 

Yunus $^{4}$

study. The results showed that the assessment questions were asked to the students after an explanation was given or after introducing a new concept to the students. In this context, teachers must request oral problems to assess the understanding and current level that students have achieved in the process of teaching mathematics implemented (Cauley \& McMillan, 2010). The information obtained by the teacher through the assessment questions helps them to plan and make the best decision on the mathematics instruction implemented.

Although teachers ask the assessment questions to find out the extent of understanding and current level of students, teachers' assessment questions are not intended to compare students, but, rather, to improve the quality of mathematicsteachers through modification of better teaching strategies to enhance students' weaknesses in learning. In this context, if students give a positive response and meet the teacher's needs, then the teacher will decide to continue teaching to the next step. However, if the answer is inaccurate or does not meet teachers' needs, teachers need to plan interventions and improve teaching strategies to help students learn. However, in implementing assessment questions, every teacher must understand that assessment questions should not focus on the understanding and cognitive aspects of students alone, but should be more holistic, including elements of knowledge, skills and values and inclusive so that they take into account all levels of students ability (Ministry of Education Malaysia, 2014)

Effective formative assessment practices through oral questioning provide good impact and outcomes to teachers. One of the effects of the implementation of formative assessment is that teachers can measure their teaching effectiveness Graham et al. (2011). Teachers can conduct a self-assessment to evaluate the effectiveness of their teaching. Teachers' teaching can be improved and enhanced if teachers find their teaching less effective and there is less response from students (Abdullah et al., 2014). Teachers also need to plan to diversify their teaching methods so that the teaching implemented will be more meaningful and successful in encouraging student involvement.

Moreover, the information gathered through formative assessment in oral questioning enables teachers to provide appropriate and accurate feedback to students. Feedback provided by teachers will help students improve their understanding of the content of the lesson and help improve the quality of their learning. However, Dibbs (2014) stated that teachers need to be innovative in giving effective information by looking at the student's level. Dibbs (2014) also stated that feedback to low-achieving students should be given immediately to correct their mistakes. Feedback to high-achieving students should be given some time to reflect and correct their errors.

Also, the results of formative assessments focused on oral questioning allow teachers to identify the level of knowledge, skills, and values that students master in mathematics learning. The use of oral questioning allows teachers to gather a lot of information, especially about the knowledge and skills that students have achieved (Good, 2011). In addition, the use of high-level oral questioning was found to supply more information about the knowledge and skills that students had gained compared to low-level questioning, which only provided less information about the knowledge and skills that students had achieved (Mahmud, 2020). By understanding the level of experience, skills, and values that students have mastered, teachers will plan and decide whether student learning can be continued to the next unit or not (Mahmud et al., 2020a).

Also, all the information that has been collected, recorded andanalysed by teachers as a result of the implementation of formative assessment helps teachers to plan teaching activities according to the developmental needs and existing knowledge of students. Activities designed according to students' abilities can help students follow the learning process better and encourage them to be actively involved in the teaching and learning process (Hayes, 2013). Also, teachers can not only plan teaching activities alone but alsocan use the information obtained through the formative assessment to plan assessment activities in the future. Furthermore, teachers are also able to identify students' strengths and weaknesses in mathematics learning from time to time. The strengths that students help teachers to make decisions about styling and reinforcement activities. In contrast, information about students' shortcomings helps teachers make decisions about interventions and remedial activities that need to be taken.Thus, the implementation of formative assessment indeed provides many positive impacts and outcomes for teachers, especially in helping them improve teaching strategies and improving and enhancing student learning .

\subsection{Conclusion}

Overall, oral questioning in teaching mathematics has a significant impact on the improvement and enhancement of the quality of teaching implemented by teachers through assessments implemented using oral questioning. Thus, teachers need to play their role as facilitators to obtain student information and provide feedback on student learning and further improve student learning based on the information obtained. This study has expanded the knowledge and perspective on how oral questioning can help teachers implement formative assessment in mathematics teaching. However, the findings of this study are relative and not absolute. There is a need for additional research to develop knowledge on the implementation of formative assessment through oral questioning.

\section{References}


1. Abdullah, M. F. N. L., Hamzah, M. S. G., Ahmad, C. N. C., Adnan, M., Noh, N. M., \& Suhaimi, S. (2014). Pembinaan Instrumen Amalan Pentaksiran Guru Matematik Sekolah Menengah [Construction of a Secondary School Mathematics Teacher Assessment Practice Instrument]. Jurnal Pendidikan Sains Dan Matematik Malaysia, 4(1), 1-14.

2. Belcher, J. O. (2016). Effectiveness Of A Formative Assessment Initiative On Student Achievement In Eighth Grade Math. Missisippi College.

3. Boulter, M. L. (2010). The influence of socratic questioning in online discussions on the critical thinking skills of undergraduate students: An exploratory study based on a business course at a proprietary university. Dissertation Abstracts International Section A: Humanities and Social Sciences, 71(4-A), $1200 . \quad$ Retrieved from http://search.ebscohost.com/login.aspx?direct=true\&db=psyh\&AN=2010-99191-133\&site=ehost-live

4. Buhagiar, M. A. (2014). The classroom assessment cycle within the alternative assessment paradigm: exploring the role of the teacher. Journal of Maltese Education Research, 4(2), 17-36.

5. Cauley, K. M., \& McMillan, J. H. (2010). Formative Assessment Techniques to Support Student Motivation and Achievement. The Clearing House: A Journal of Educational Strategies, Issues and Ideas, 83(1), 1-6.

6. Curriculum Development Division. (2014). Elemen KBAT Dalam Pentaksiran [HOTS Element in Assessment]. Putrajaya: Kementerian Pendidikan Malaysia.

7. Desli, D., \& Galanopoulou, E. (2017). Questioning in Primary School Mathematics: An Analysis of Questions Teachers Ask in Mathematics Lessons. 3rd International Symposium on New Issues on Teacher Education, 97.

8. Dibbs, R.-A. (2014). The Effects Of Formative Assessment On Students' Zone Of Proximal Development In Introductory Calculus. College of Natural and Health Sciences School.

9. Franke, M. L., Webb, N. M., Chan, A. G., Ing, M., Freund, D., \& Battey, D. (2009). Teacher Questioning to Elicit Students' Mathematical Thinking in Elementary School Classrooms. Journal of Teacher Education, 60(4), 380-392. https://doi.org/doi:10.1177/0022487109339906

10. Good, R. (2011). Formative Use of Assessment Information : It' s a Process, So Let's Say What We Mean. Practical Assessment, Research \& Evaluation, 16(3), 1-6.

11. Graham, S., Harris, K., \& Hebert, M. (2011). The Benefits of Formative Assessment. New York: Carnegie Corporation of New York.

12. Harlen, W. \& Q. A. (2004). The Teaching Of Science in Primary Schools (4th ed.). London: David Fulton Publisher Ltd.

13. Iksan, Z. H., \& Daniel, E. (2015). Emerging Model of Questioning through the Process of Teaching and Learning Electrochemistry. International Education Studies, 8(10). https://doi.org/10.5539/ies.v8n10p137

14. Kassim, N., \& Zakaria, E. (2013). Integrasi Kemahiran Berfikir Aras Tinggi dalam Pengajaran dan Pembelajaran Matematik: Analisis Keperluan Guru [Integration of High-Level Thinking Skills in the Teaching and Learning of Mathematics: An Analysis of Teacher Needs]. Jurnal Pendidikan Matematik [Journal of Mathematics Education], 3(1), 1-12.

15. Kim, J., Kwon, Y., \& Cho, D. (2011). Investigating factors that influence social presence and learning outcomes in distance higher education. Computers \& Education, 57(2), 1512-1520.

16. Kolb, S. M. (2012). Grounded Theory and the Constant Comparative Method: Valid Research Strategies for Educators. Journal of Emerging Trends in Educational Research and Policy Studies, 3(1), 83-86.

17. Mahmud, M. S. (2019). The Role of Wait Time in the Process of Oral Questioning in the Teaching and Learning Process of Mathematics. International Journal of Advanced Science and Technology Vol., 28(16), 691-697.

18. Mahmud, M. S. (2020). Level of Oral Questions Used by New and Experience Teachers in Mathematics Teaching in Primary Schools. International Journal of Psychosocial Rehabilitation, 24(8), 3533-3541.

19. Mahmud, M. S., \& Yunus, A. S. M. (2018). The Practice Of Giving Feedback Of Primary School Mathematics Teachers In Oral Questioning Activities. Journal of Advanced Research in Dynamical and Control Systems, 10(12), 1336-1343.

20. Mahmud, M. S., Yunus, A. S. M., Ayub, A. F. M., \& Sulaiman, T. (2020a). Enhancing Mathematical Language Through Oral Questioning in Primary School. International Journal of Learning, Teaching and Educational Research, 19(5), 395-410.

21. Mahmud, M. S., Yunus, A. S. M., Ayub, A. F. M., \& Sulaiman, T. (2020b). The use of oral questioning in inculcating values in mathematics for primary school students. Universal Journal of Educational Research, 8(3), 1-8. https://doi.org/10.13189/ujer.2020.081601

22. Mahmud, M. S., Yunus, A. S. M., Ayub, A. F. M., \& Sulaiman, T. (2020c). Types of Oral Questions 
Used by Teachers in Mathematical Problem Solving Teaching in Primary School Mathematics Teaching. International Journal of Psychosocial Rehabilitation, 24(06), 2278-2292.

23. Marshall, C., \& Rossman, G. B. (2014). Designing Qualitative Research. California: SAGE Publications, Incorporated.

24. Merriam, S. B., \& Tisdell, E. J. (2016). Qualitative Research A Guide to Design and Implementation. San Francisco: Jossey-Bass Inc Pub.

25. Ministry of Education Malaysia. (2014). Dokumen Standard Kurikulum Dan Pentaksiran Matematik Tahun Enam [Curriculum and Assessment Standard Documents: Year Six Mathematics]. Putrajaya: Ministry of Education Malaysia.

26. Mutalib, S. A., \& Ahmad, J. (2012). Penggunaan Teknik Pentaksiran Formatif Dalam Subjek Bahasa Melayu Darjah Satu: Kajian Kes [Use of Formative Assessment Techniques in Malay Language Subject for Standard One: Case Study]. Malay Language Education Journal, 17-30.

27. Nancy, D., \& Frey, F. (2015). Checking for Understanding: Formative Assessment Techniques for Your Classroom. Alexandria: ASCD.

28. Sach, E. (2012). Teachers and testing: an investigation into teachers' perceptions of formative assessment. Educational Studies, 38(3), 261-276.

29. Shahrill, M. (2013). Review of Effective Teacher Questioning in Mathematics Classrooms. International Journal of Humanities and Social Science, 3(17), 224-231.

30. Watt, H. M. G., Shapka, J. D., Morris, Z. A., Durik, A. M., Keating, D. P., \& Eccles, J. S. (2012). Gendered motivational processes affecting high school mathematics participation, educational aspirations, and career plans: A comparison of samples from Australia, Canada, and the United States. Developmental Psychology, 48(6), 1594.

31. Weiland, I., Hudson, R., \& Amador, J. (2014). Preservice formative assessment interviews: The development of competent questioning. International Journal of Science \& Mathematics Education, 12(2), 329-352.

32. Wong, K. Y. (2015). Use of Student Mathematics Questioning to Promote Active Learning and Metacognition. In S. J. Cho (Ed.), Selected Regular Lectures from the 12th International Congress on Mathematical Education (pp. 877-895). https://doi.org/10.1007/978-3-319-17187-6_49

33. Zakaria, E., \& Addenan, N. (2015). Isu Pengajaran Dalam Kalangan Guru matematik. In Isu Dan Cabaran Dalam Pendidikan Matematik (pp. 1-18). Bangi: Penerbit Universiti Kebangsaan Malaysia. 